\title{
Solid State Characterization of the Consciousness Energy Healing Treated Magnesium
}

\author{
Gopal Nayak ${ }^{1}$, Mahendra Kumar Trivedi ${ }^{1}$, Alice Branton ${ }^{1}$, Dahryn Trivedi $^{1}$ and Snehasis Jana $^{2 *}$ \\ ${ }^{1}$ Trivedi Global, Inc., Henderson, USA
}

${ }^{2}$ Trivedi Science Research Laboratory Pvt. Ltd, India

*Corresponding author: Snehasis Jana, Trivedi Science Research Laboratory Pvt. Ltd, Thane (W), India

\begin{abstract}
Magnesium (Mg) is abundantly present in the human body, which is important for many metabolic activities, and normal functioning of cells, muscles, heart, bones, etc. The objective of this study was to evaluate the impact of the Trivedi Effect ${ }^{\circledR}$ on the physicochemical properties of Mg powder using PXRD and PSA analytical techniques. Mg powder sample was divided into two parts, one part of Mg was considered as control (no Biofield Energy Treatment was provided), while the second part received the Consciousness Energy Healing Treatment remotely by a renowned Biofield Energy Healer, Gopal Nayak and termed as a Consciousness Energy Healing Treated sample. The PXRD peak intensities and crystallite sizes of the treated Mg were significantly altered ranging from $2.86 \%$ to $16.51 \%$ and $6.79 \%$ to $52.30 \%$, respectively compared to the control sample. Overall the average crystallite size of the treated Mg sample was significantly increased by $16.92 \%$ compared with the control sample. The particle size values in the treated Mg were significantly decreased by $5.5 \%\left(\mathrm{~d}_{10}\right), 7.26 \%\left(\mathrm{~d}_{50}\right), 8.63 \%\left(\mathrm{~d}_{90}\right)$, and $7.69 \%\{\mathrm{D}(4,3)\}$ compared to the control sample. The specific surface area of Consciousness Energy Healing Treated $\mathrm{Mg}$ powder $\left(0.0187 \mathrm{~m}^{2} / \mathrm{g}\right)$ was significantly increased by $7.47 \%$ compared with the control sample $\left(0.0174 \mathrm{~m}^{2} / \mathrm{g}\right)$. The Trivedi Effect ${ }^{\circledR}$ might lead to generate a new polymorphic form of Mg which would show better solubility in solvents compared with the control sample. The Consciousness Energy Healing Treated Mg would be very useful for the prevention and treatment of many diseases such as hypomagnesaemia, ventricular arrhythmias and the prevention of sudden cardiac death, migraine, inflammatory diseases, immunological disorders, pre-eclampsia, eclampsia, diabetes mellitus, cancer, gestational hypertension, oxidative stress, etc. It would be more beneficial for the designing of nutraceutical/ pharmaceutical formulations, and other metal and chemical industries.
\end{abstract}

Keywords: Magnesium, The Trivedi Effect ${ }^{\circledR}$, Consciousness Energy Healing Treatment, PXRD, Particle size

\section{Introduction}

Magnesium (Mg) is abundantly present in the human body, which functions for many metabolic activities, normal functioning of cells, muscles, heart, bones, etc. [1]. $\mathrm{Mg}^{++}$ions also have the functions with ATP, RNA, and DNA in the body [2,3]. Dietary sources that contain reach $\mathrm{Mg}$ are nuts, cereals, cocoa, spices, and green leafy vegetables [2]. Other than this numerous sources for Mg are nutraceutical and pharmaceutical preparations, i.e., Mg gluconate, citrate, chloride, aspartate, or lactate [4]. Deficiency of plasma Mg (called hypomagnesaemia) is a very general problem in most of the population [5]. Hypomagnesaemia mainly occurs due to the low magnesium dietary intake, an increased intracellular shift, increased renal or gastrointestinal loss, proton-pump inhibitor and antacid therapy, alcoholism, type 2 diabetes, hypertension [5-
7]. $\mathrm{Mg}$ has a great role in the prevention and treatment of many diseases such as hypomagnesaemia, ventricular arrhythmias, sudden cardiac death, pre-eclampsia, migraine, eclampsia, etc. [2, 8-10]. Mg salt also has numerous applications in nutraceutical and pharmaceutical industry for the inflammatory diseases, immunological disorders, diabetes mellitus, allergies, cancer, septic shock, asthma, gestational hypertension, oxidative stress, hearing loss, etc. Salt of Mg also used as a potent antioxidant agent, laxative, antacid, neuroprotective, oral tocolytic agent, and skin-tightening antiaging cosmetic composition [2,11-16]. In heavy industry $\mathrm{Mg}$ used for the structural metal, aluminium alloys, die-casting, aircraft, automobiles, reagents in the organic synthesis, manufacturing of mobile phones, laptop and tablet computers, cameras, and other 
electronic components [2-17]. Mg can be explosive hazards; it is highly reactive with water, flammable at the temperature of approximately $3100{ }^{\circ} \mathrm{C}$ and the auto-ignition at the temperature of $473^{\circ} \mathrm{C}[2-18]$.

The physicochemical properties of any materials play a crucial role in the operational point of views. Scientifically, the Biofield Energy Healing Treatment (Trivedi Effect ${ }^{\circledR}$ ) has proven with potential impact altering the physicochemical properties and thermal properties of any objects [19-21]. The Trivedi Effect ${ }^{\circledR}$ is a natural and only scientifically proven phenomenon. In this case, a person can harness this inherently intelligent energy from the Universe and transfer it to any objects anywhere on the planet via the possible mediation of neutrinos [22]. Every individual possesses a unique energy field which genertes in the body known as "Biofield". The "Biofield" is infinite, para-dimensional electromagnetic field. The "Biofield" based Energy Healing Therapies have significant results against various disease conditions [23]. The National Institutes of Health (NIH) and National Center for Complementary and Alternative Medicine (NCCAM) recommend and included the Energy therapy under Complementary and Alternative Medicine (CAM) category. CAM therapy has been accepted by most of the U.S. population [24,25]. The Trivedi Effect ${ }^{\circledR}$-Consciousness Energy Healing Treatment is one the important CAM which has outstanding outcome-altering the properties of metals, ceramic, organic compounds, nutraceuticals, pharmaceuticals, cancer cells, microorganisms, and crops [26-39]. In this study, the impact of the Trivedi Effect ${ }^{\circledR}$-Consciousness Energy Healing Treatment on the physicochemical, and thermal properties of Mg was evaluated using powder X-ray diffraction and particle size analysis.

\section{Materials and Methods}

\section{Chemicals and Reagents}

The test sample Mg powder was purchased from Sigma Aldrich, the USA, and other chemicals were of analytical grade purchased in India for the experiment.

\section{Consciousness Energy Healing Treatment Strategies}

Based on the sample treatment procedure the $\mathrm{Mg}$ powder sample was divided into two equal parts and termed as control and Consciousness Energy Healing Treated sample. The Biofield Energy Treatment was not provided to the control Mg sample but was treated with a "sham" healer, who did not have any knowledge about the Biofield Energy Treatment. However, the treated Mg has received the Trivedi Effect $(\AA$-Consciousness Energy Healing Treatment remotely for 3 minutes under standard laboratory conditions. This treatment was a unique energy transmission process performed by the renowned Biofield Energy Healer, Gopal Nayak, India. After the treatment, the Consciousness Energy Healing
Treated and control samples were kept in a sealed condition and characterized using modern analytical techniques.

\section{Characterization}

The Powder X-ray diffraction (PXRD) analysis of control and Consciousness Energy Healing Treated Mg powder was performed with the help of Rigaku MiniFlex-II Desktop X-ray diffractometer (Japan) [40,41]. The average size of individual crystallites was calculated from XRD data using the Scherrer's formula (1)

$\mathrm{G}=\mathrm{k} \lambda / \beta \cos \theta$

Where $\mathrm{k}$ is the equipment constant, $\mathrm{G}$ is the crystallite size in $\mathrm{nm}$, $\lambda$ is the radiation wavelength, $\beta$ is the full-width at half maximum, and $\theta$ is the Bragg angle [42]. Similarly, the particle size analysis of Mg powder samples was conducted on Malvern Mastersizer 2000 (UK) using a wet method $[43,44]$. The $\%$ change in the crystallite size, peak intensity, particle size, and surface area were calculated using the following equation 2 :

$\%$ change $=[($ Treated - Control $) /$ Control $] \times 100$

\section{Results and Discussion \\ Powder X-ray Diffraction (PXRD) Analysis}

The control and treated Mg powder sample showed sharp and intense peaks in the PXRD diffractograms (Figure 1), which indicated that both the samples were crystalline in nature. The diffractograms of the control and treated Mg samples showed the highest peak intensity at $2 \theta$ equal to $37.99^{\circ}$ and $37.99^{\circ}$, respectively (Table 1, entry 3). All the peak intensities of the treated Mg were significantly altered ranging from $2.86 \%$ to $16.51 \%$ compared with the control sample. The crystallite sizes of the Consciousness Energy Healing Treated Mg were significantly altered ranging from $6.79 \%$ to $52.30 \%$ compared with the control sample. However, the average crystallite size of the Consciousness Energy Healing Treated Mg powder sample was significantly increased by $16.92 \%$ compared with the control sample. The differences in the crystallite sizes and peak intensities of Mg powder crystals indicated the modification of the crystal morphology of the treated sample compared with the control sample. The peak intensity of the crystalline compound changes according to the crystal morphology [45]. The alterations in the PXRD pattern gives us proof of polymorphic transitions [46]. The Trivedi Effect ${ }^{\circledR}$ probably responsible for the production of the new polymorphic form of Mg through Consciousness Energy via neutrino oscillation [22]. The polymorphic character of any compounds has significant effects on its thermodynamic and other physicochemical properties. The Consciousness Energy Healing Treated Mg would be better for designing better nutraceutical/ pharmaceutical formulations and other industrial applications. 

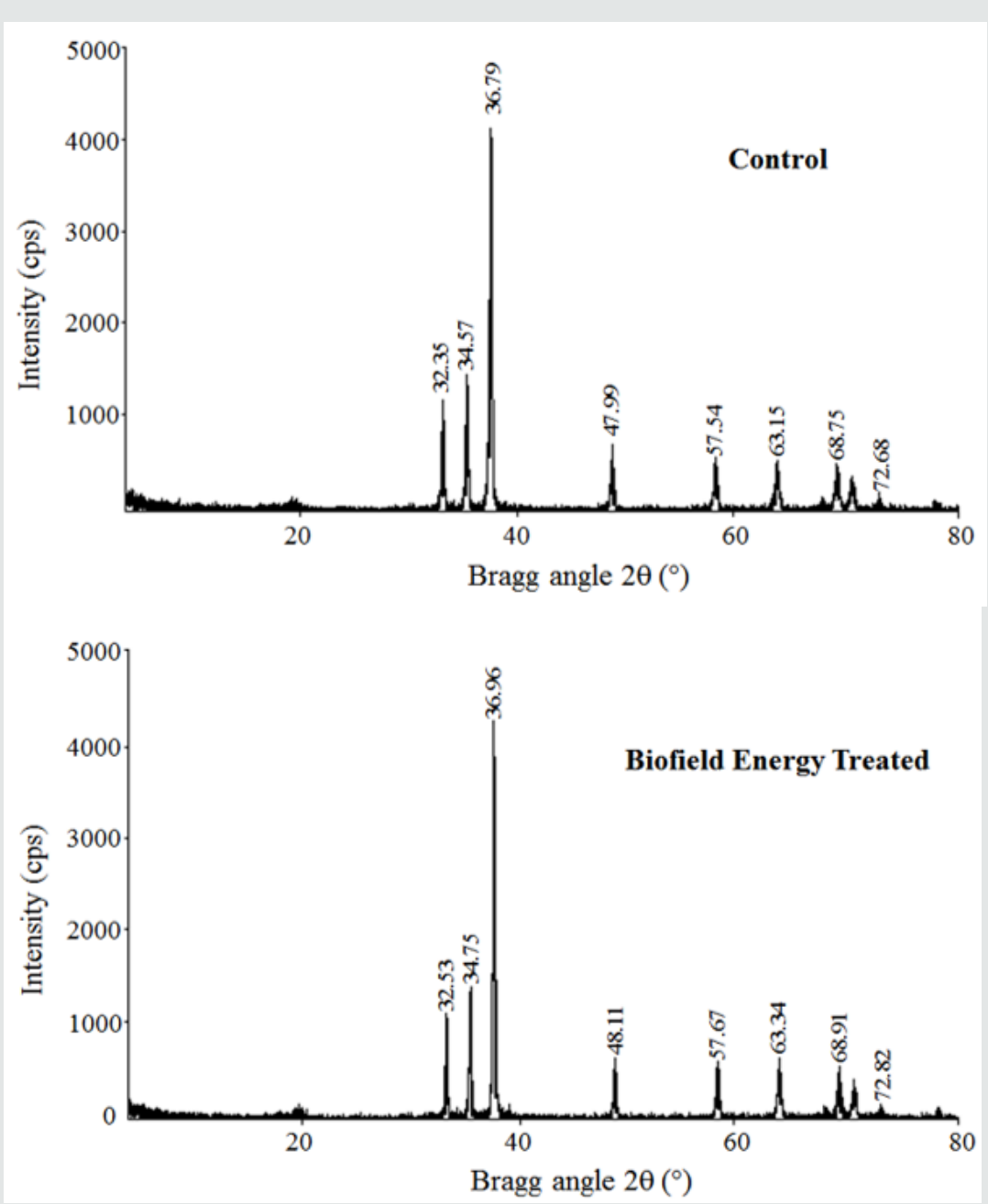

Figure 1: PXRD diffractograms of the control and treated $\mathrm{Mg}$ powder.

Table 1: PXRD data for the control and treated Mg powder.

\begin{tabular}{|ccccccccc|}
\hline \multirow{2}{*}{ Entry No } & \multicolumn{2}{c}{ Bragg angle $\left({ }^{\circ} \mathbf{2} \boldsymbol{\theta}\right.$ ) } & \multicolumn{3}{c}{ Peak Intensity (\%) } & \multicolumn{3}{c|}{ Crystallite size (G, nm) } \\
\cline { 2 - 9 } & Control & Treated & Control & Treated & \% change & Control & Treated & \% change \\
\hline 1 & 32.35 & 32.53 & 218.00 & 182.00 & -16.51 & 357.00 & 398.00 & 11.48 \\
2 & 34.57 & 34.75 & 269.00 & 239.00 & -11.15 & 350.00 & 409.00 & 16.86 \\
3 & 36.79 & 36.96 & 872.00 & 783.00 & -10.21 & 334.00 & 374.00 & 11.98 \\
4 & 47.99 & 48.11 & 133.00 & 115.00 & -13.53 & 323.00 & 371.00 & 14.86 \\
5 & 57.54 & 57.67 & 133.00 & 122.00 & -8.27 & 284.00 & 351.00 & 23.59 \\
6 & 63.15 & 63.34 & 140.00 & 144.00 & 2.86 & 264.00 & 310.00 & 17.42 \\
7 & 67.46 & 67.57 & 15.00 & 12.80 & -14.67 & 312.00 & 340.00 & 8.97 \\
8 & 68.75 & 68.91 & 136.00 & 127.00 & -6.62 & 239.00 & 364.00 & 52.30 \\
9 & 72.68 & 72.82 & 13.80 & 14.10 & 2.17 & 368.00 & 393.00 & 6.79 \\
10 & & & Average crystallite size & & & 314.56 & 367.78 & 16.92 \\
\hline
\end{tabular}

\section{Particle Size Analysis (PSA)}

The particle size distribution data of both the Mg powder samples are presented in Table 2. Therefore, the particle size values in the Consciousness Energy Healing Treated Mg were significantly decreased by $5.5 \%\left(d_{10}\right), 7.26 \%\left(d_{50}\right), 8.63 \%\left(d_{90}\right)$, and $7.69 \%\{D$ $(4,3)\}$, respectively compared to the control sample. The specific surface area of Consciousness Energy Healing Treated Mg powder $\left(0.0187 \mathrm{~m}^{2} / \mathrm{g}\right)$ was significantly increased by $7.47 \%$ compared with the control sample $\left(0.0174 \mathrm{~m}^{2} / \mathrm{g}\right)$. The results of PSD indicated that the Trivedi Effect ${ }^{\circledR}$ might be acting like an external force for breaking the larger Mg particle to the smaller size. Thus, increased the surface area of the Consciousness Energy Healing Treated Mg compared to the control sample. Reducing the particle size and 
increased surface area of Mg definitely alter its physicochemical and thermal behaviour. Thus, the Consciousness Energy Healing Treated Mg might offer better solubility and bioavailability compared to the control sample. particle diameter corresponding to $10 \%, 50 \%$, and $90 \%$ of the cumulative distribution, D $(4,3)$ : the average mass-volume diameter, and SSA: the specific surface area.

Table 2: Particle size distribution of the control and treated Mg powder.

\begin{tabular}{|c|c|c|c|c|c|}
\hline Parameter & $d_{10}(\mu \mathrm{m})$ & $d_{50}(\mu \mathrm{m})$ & $d_{90}(\mu \mathrm{m})$ & $\mathrm{D}(4,3)(\mu \mathrm{m})$ & $\mathrm{SSA}\left(\mathrm{m}^{2} / \mathrm{g}\right)$ \\
\hline Control & 210.72 & 406.91 & 724.22 & 439.92 & 0.0174 \\
\hline Biofield Energy Treated & 199.14 & 377.36 & 661.70 & 406.07 & 0.0187 \\
\hline Percent change (\%) & -5.50 & -7.26 & -8.63 & -7.69 & 7.47 \\
\hline
\end{tabular}

\section{Conclusion}

The impact of the Trivedi Effect ${ }^{\circledR}$ Consciousness Energy Healing Treatment on the Mg powder sample was significant. The PXRD peak intensities and crystallite sizes of the Consciousness Energy Healing Treated Mg were significantly altered ranging from $2.86 \%$ to $16.51 \%$ and $6.79 \%$ to $52.30 \%$, respectively compared to the control sample. Overall the average crystallite size of the Consciousness Energy Healing Treated Mg sample was significantly increased by $16.92 \%$ compared with the control sample. The particle size values in the Consciousness Energy Healing Treated Mg were significantly decreased by $5.5 \%\left(\mathrm{~d}_{10}\right), 7.26 \%\left(\mathrm{~d}_{50}\right), 8.63 \%\left(\mathrm{~d}_{90}\right)$, and $7.69 \%$ $\{\mathrm{D}(4,3)\}$ compared to the control sample. The specific surface area of Consciousness Energy Healing Treated Mg powder $\left(0.0187 \mathrm{~m}^{2} / \mathrm{g}\right)$ was significantly increased by $7.47 \%$ compared with the control sample $\left(0.0174 \mathrm{~m}^{2} / \mathrm{g}\right)$. The Trivedi Effect ${ }^{\circledR}$ might lead to generate a new polymorphic form of $\mathrm{Mg}$ which would show better solubility in solvents compared with the control sample. The Consciousness Energy Healing Treated Mg would be very useful for the prevention and treatment of many diseases such as hypomagnesaemia, ventricular arrhythmias and the prevention of sudden cardiac death, pre-eclampsia, eclampsia, migraine, inflammatory diseases, immunological disorders, diabetes mellitus, allergies, cancer, septic shock, asthma, gestational hypertension, oxidative stress, hearing loss, etc. It would be more beneficial for the designing of nutraceutical/pharmaceutical formulations, and other metal and chemical industries.

\section{Acknowledgements}

The authors are grateful to Central Leather Research Institute, SIPRA Lab. Ltd., Trivedi Science, Trivedi Global, Inc., Trivedi Testimonials, and Trivedi Master Wellness for their assistance and support during this work.

\section{References}

1. Guerrera MP, Volpe SL, Mao JJ (2009) Therapeutic uses of magnesium. Am Fam Physician 80: 157-162.

2. Saris NE, Mervaala E, Karppanen H, Khawaja JA, Lewenstam A (2000) Magnesium. An update on physiological, clinical and analytical aspects. Clin Chim Acta 294: 1-26.

3. https://en.wikipedia.org/wiki/Magnesium.

4. Firoz M, Graber M (2001) Bioavailability of US commercial magnesium preparations. Magnes Res 14: 257-262.
5. Ayuk J, Gittoes NJ (2014) Contemporary view of the clinical relevance of magnesium homeostasis. Ann Clin Biochem 51: 179-188.

6. William JH, Danziger J (2016) Magnesium deficiency and proton-pump inhibitor use: A clinical review. J Clin Pharmacol 56: 660-668.

7. Geiger H, Wanner C (2012) Magnesium in disease. Clin Kidney J 5 (Suppl 1): i25-i38.

8. Zipes DP, Camm AJ, Borggrefe M (2012) ACC/AHA/ESC 2006 Guidelines for Management of Patients With Ventricular Arrhythmias and the Prevention of Sudden Cardiac Death: a report of the American College of Cardiology/American Heart Association Task Force and the European Society of Cardiology Committee for Practice Guidelines (writing committee to develop Guidelines for Management of Patients With Ventricular Arrhythmias and the Prevention of Sudden Cardiac Death): developed in collaboration with the European Heart Rhythm Association and the Heart Rhythm Society. Circulation 114: e385-e484.

9. Teigen L, Boes CJ (2015) An evidence-based review of oral magnesium supplementation in the preventive treatment of migraine. Cephalalgia 35: $912-922$.

10. James MF (2010) Magnesium in obstetrics. Best Pract Res Clin Obstet Gynaecol 24: 327-337.

11. Branton A, Jana S (2017) Impact of consciousness energy healing treatment on the physicochemical and thermal properties of magnesium gluconate. American Journal of Chemical Engineering 5: 64-73.

12. Vasant G, Krishnamurthy VP, Sudha G, Manik D, Kalyani P (2009) The Fertilizer Encyclopedia p. 224.

13. Fleming TE, Mansmann Jr HC (1999) Methods and compositions for the prevention and treatment of diabetes mellitus. United States Patent, p. $1-10$.

14. Turner RJ, Dasilva KW, O’Connor C, van den Heuvel C, Vink R (2004) Magnesium gluconate offers no more protection than magnesium sulphate following diffuse trau-matic braininjury in rats. J Am Coll Nutr 23: 541S-544S.

15. Martin RW, Martin JN Jr, Pryor JA, Gaddy DK, Wiser WL, Morrison JC (1988) Comparison of oral ritodrine and magnesium gluconate for ambulatory tocolysis. Am J Obstet Gynecol 158: 1440-1445.

16. Dreizin EL, Berman CH, Vicenzi EP (2000) Condensed-phase modifications in magnesium particle combustion in air. Scripta Materialia 122: 30-42.

17. Trivedi MK, Patil S, Shettigar H, Singh R, Jana S (2015) An impact of biofield treatment on spectroscopic characterization of pharmaceutical compounds. Mod Chem appl 3: 159.

18. Trivedi MK, Tallapragada RM, Branton A, Trivedi D, Nayak G, Latiyal O, Jana S (2015) Potential impact of biofield treatment on atomic and physical characteristics of magnesium. Vitam Miner 3: 129.

19. Dabhade VV, Tallapragada RMR, Trivedi MK (2009) Effect of external energy on the atomic, crystalline, and powder characteristics of antimony and bismuth powders. Bulletin of Materials Science 32: 471479 . 
20. Trivedi MK, Mohan TRR (2016) Biofield energy signals, energy transmission and neutrinos. American Journal of Modern Physics 5: 172-176.

21. Rubik B, Muehsam D, Hammerschlag R, Jain S (2015) Biofield science and healing: history, terminology, and concepts. Glob Adv Health Med 4: 8-14.

22. Barnes PM, Bloom B, Nahin RL (2008) Complementary and alternative medicine use among adults and children: United States, 2007. Natl Health Stat Report 12: 1-23.

23. Koithan M (2009) Introducing complementary and alternative therapies. J Nurse Pract 5(1): 18-20.

24. Nayak G, Trivedi MK, Branton A, Trivedi D, Jana S (2018) Evaluation of the physicochemical and thermal properties of chromium trioxide (CrO3): Impact of consciousness energy healing treatment. Research \& Development in Material Science 8: 1-6.

25. Trivedi MK, Branton A, Trivedi D, Nayak G, Panda P, Jana S (2016) Evaluation of the isotopic abundance ratio in biofield energy treated resorcinol using gas chromatography-mass spectrometry technique. Pharm Anal Acta 7: 481.

26. Trivedi MK, Branton A, Trivedi D, Nayak G, Sethi KK, Jana S (2016) Determination of isotopic abundance ratio of biofield energy treated 1,4-dichlorobenzene using gas chromatography-mass spectrometry (GC-MS). Modern Chemistry 4: 30-37.

27. Nayak G, Trivedi MK, Branton A, Trivedi D, Jana S (2018) Evaluation of the consciousness energy healing treated berberine chloride using PXRD, PSA, and DSC Analysis. Food Sci Nutr Technol.

28. Nayak G, Trivedi MK, Branton A, Trivedi D, Jana S (2018) Impact of Consciousness energy healing treatment on the physicochemical and thermal properties of vitamin D3 (cholecalciferol). Food Sci Nutr Technol.

29. Branton A, Trivedi MK, Trivedi D, Nayak G (2018) Evaluation of the physicochemical and thermal properties of the biofield energy healing treated ofloxacin. J Pharm Pharmaceutics 5: 80-87.

30. Nayak G, Trivedi MK, Branton A, Trivedi D, Jana S (2018) Consciousness energy healing treatment: Impact on physicochemical and thermal properties of silver sulfadiazine. Journal of advanced pharmaceutical science and technology 2:1-13.

31. Trivedi MK, Patil S, Shettigar H, Mondal SC, Jana S (2015) The Potential Impact of Biofield Treatment on Human Brain Tumor Cells: A TimeLapse Video Microscopy. J Integr Oncol 4: 141

32. Trivedi MK, Patil S, Shettigar H, Gangwar M, Jana S (2015) In Vitro Evaluation of Biofield Treatment on Cancer Biomarkers Involved in Endometrial and Prostate Cancer Cell Lines. J Cancer Sci Ther 7: 253257.

33. Trivedi MK, Patil S, Shettigar H, Mondal SC, Jana S (2015) Evaluation of Biofield Modality on Viral Load of Hepatitis B and C Viruses. J Antivir Antiretrovir 7: 083-088.
34. Trivedi MK, Patil S, Shettigar H, Mondal SC, Jana S (2015) In vitro evaluation of biofield treatment on Enterobacter cloacae: Impact on antimicrobial susceptibility and biotype. J Bacteriol Parasitol 6: 241.

35. Sances F, Flora E, Patil S, Spence A, Shinde V (2013) Impact of biofield treatment on ginseng and organic blueberry yield. AGRIVITA, Journal of Agricultural Science 35: 22-29.

36. Trivedi MK, Branton A, Trivedi D, Nayak G, Gangwar M, Jana S (2015) Agronomic characteristics, growth analysis, and yield response of biofield treated mustard, cowpea, horse gram, and groundnuts. International Journal of Genetics and Genomics 3: 74-80.

37. (1997) Desktop X-ray Diffractometer "MiniFlex+". The Rigaku Journal 14: $29-36$

38. Zhang T, Paluch K, Scalabrino G, Frankish N, Healy AM, Sheridan H (2015) Molecular structure studies of (1S,2S)-2-benzyl-2,3-dihydro-2(1Hinden-2-yl)-1H-inden-1-ol. J Mol Struct 1083: 286-299.

39. Langford JI, Wilson AJC (1978) Scherrer after sixty years: A survey and some new results in the determination of crystallite size. J Appl Cryst 11: 102-113.

40. Trivedi MK, Sethi KK, Panda P, Jana S (2017) A comprehensive physicochemical, thermal, and spectroscopic characterization of zinc (II) chloride using Xray diffraction, particle size distribution, differential scanning calorimetry, thermogravimetric analysis/ differential thermogravimetric analysis, ultravioletvisible, and Fourier transforminfrared spectroscopy. International Journal of Pharmaceutical Investigation 7: 33-40.

41. Trivedi MK, Sethi KK, Panda P, Jana S (2017) Physicochemical, thermal and spectroscopic characterization of sodium selenate using XRD, PSD, DSC, TGA/DTG, UV-vis, and FT-IR. Marmara Pharmaceutical Journal 21(2): 311-318.

42. Inoue M, Hirasawa I (2013) The relationship between crystal morphology and XRD peak intensity on CaSO4.2H2O. J Crystal Growth 380: 169-175.

43. Raza K, Kumar P, Ratan S, Malik R, Arora S (2014) Polymorphism: The phenomenon affecting the performance of drugs. SOJ Pharm Pharm Sci 1: 10 .

44. Brittain HG (2009) Polymorphism in pharmaceutical solids in Drugs and Pharmaceutical Sciences, volume 192, (2nd edn), Informa Healthcare USA, Inc, New York.

45. Censi R, Martino PD (2015) Polymorph Impact on the Bioavailability and Stability of Poorly Soluble Drugs. Molecules 20: 18759-18776.

46. Blagden N, de Matas M, Gavan PT, York P (2007) Crystal engineering of active pharmaceutical ingredients to improve solubility and dissolution rates. Adv Drug Deliv Rev 59: 617-630.
CC This work is licensed under Creative Commons Attribution 4.0 License

To Submit Your Article Click Here: Submit Article

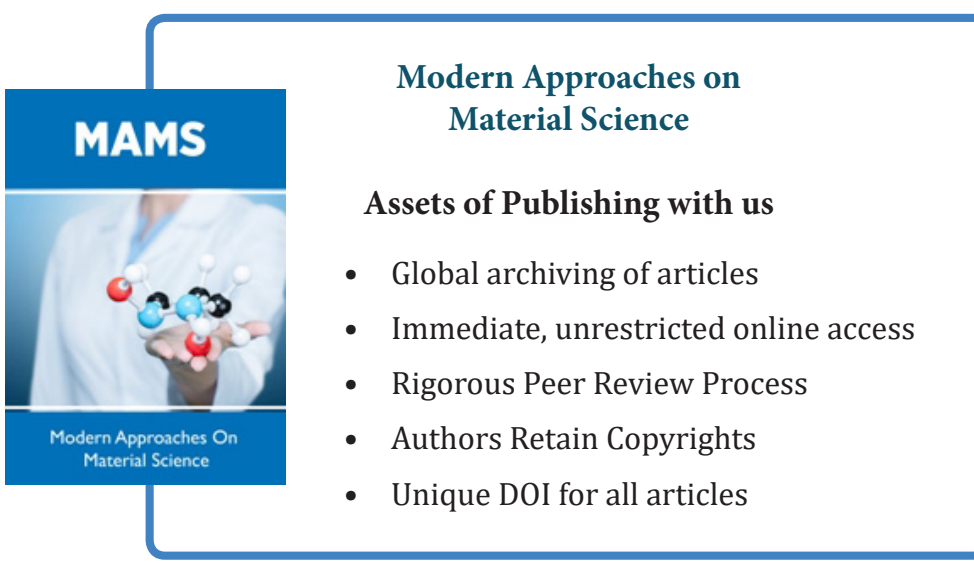

